\title{
The remarkable Dr Robertson
}

\author{
TANSY C. HAMMARTON* \\ Institute of Infection, Immunity and Inflammation, University of Glasgow, Glasgow G12 8QQ, UK
}

(Received 27 Fuly 2016; revised 21 October 2016; accepted 25 October 2016; first published online 23 November 2016)

\section{SUMMARY}

Muriel Robertson (1883-1973) was a pioneering protozoologist who made a staggering number of important contributions to the fields of parasitology, bacteriology and immunology during her career, which spanned nearly 60 years. These contributions were all the more remarkable given the scientific and social times in which she worked. While Muriel is perhaps best known for her work on the life cycle and transmission of the African trypanosome, Trypanosoma brucei, which she carried out in Uganda at the height of a major Sleeping Sickness epidemic, her work on the Clostridia during the First and Second World Wars made significant contributions to the understanding of anaerobes and to the development of anti-toxoid vaccines, and her work on the immunology of Trichomonas foetus infections in cattle, carried out in collaboration with the veterinarian W. R. Kerr, resulted in changes in farming practices that very quickly eradicated trichomoniasis from cattle herds in Northern Ireland. The significance of her work was recognized with the award of Fellow of the Royal Society in 1947 and an Honorary Doctorate of Law from the University of Glasgow, where she had earlier studied, in 1948.

Key words: Muriel Robertson, University of Glasgow, Parasitology, Protozoology, Trypanosoma spp., life cycle, Clostridium spp., Bodo caudatus, Trichomonas foetus, immunology.

\section{INTRODUCTION}

Muriel Robertson (1883-1973; Fig. 1) was a gifted scientist who had very astute observational skills and great technical expertise, together with a high capacity for critical analysis and outstanding deductive powers of reasoning. She has often been described as a formidable woman, and displayed great scientific rigour, expecting others to operate to her own very high standards, yet she was always polite and had a caring nature, and strongly believed in broadly educating the next generation. Today, Muriel is probably most famous for unravelling the life cycle and aspects of transmission of the African trypanosome, Trypanosoma brucei, although she also determined the life cycles of the freshwater green alga parasite, Pseudospora volvocis, other trypanosomes of fish and reptiles, and Trypanosoma congolense. During the First and Second World Wars, Muriel switched her attention to the Clostridia, performing various toxicological studies, helping to produce tetanus antitoxin and later helping in the development of anti-toxoid vaccines for soldiers and others at risk. In the last 20 years of her career, Muriel switched topic again to work on the immunology of Trichomonas foetus infections in collaboration with the veterinarian W. R. Kerr from Northern Ireland, and their work led to changes in farming practices that essentially wiped out trichomoniasis from

* Corresponding author: Institute of Infection, Immunity and Inflammation, University of Glasgow, 120 University Place, Glasgow G12 8TA, UK. E-mail: Tansy.Hammarton@glasgow.ac.uk cattle in Northern Ireland within 3 years. Despite losing one eye due to glaucoma in the late 1950s, she continued to work for several years until ill health and poor vision meant she could no longer meet her own high standards, forcing her retiral from bench work. She spent her last years in Limavady, Northern Ireland.

\section{Early life}

Muriel was born in Glasgow in 1883 into a large, well-to-do family as the seventh child (fourth girl) of 12 (Fig. 1A), and had the upbringing of an Edwardian gentlewoman, receiving a private, liberal arts education at home (Bishop and Miles, 1974). Her mother, Elizabeth Ritter, an Australian, was gifted at languages, a talent inherited by Muriel, and had a broad knowledge of literature. Muriel, along with some of her siblings, was taught by governesses at home, learning French and German from an early age, becoming fluent in each, and later also learned Latin and Maths under the guidance of a hired tutor. Her language skills were to prove very useful later for reading international scientific papers. She added Luganda to the list of languages she could speak fluently when she was in Uganda, often, after her return from Africa, breaking out mid-sentence into Luganda when talking about her time there. She also enjoyed music and watercolour painting, perhaps taking after one of her aunts who was a member of the Royal Academy and painted her portrait as a child (Fig. 1B). Muriel's father, Robert Andrew 

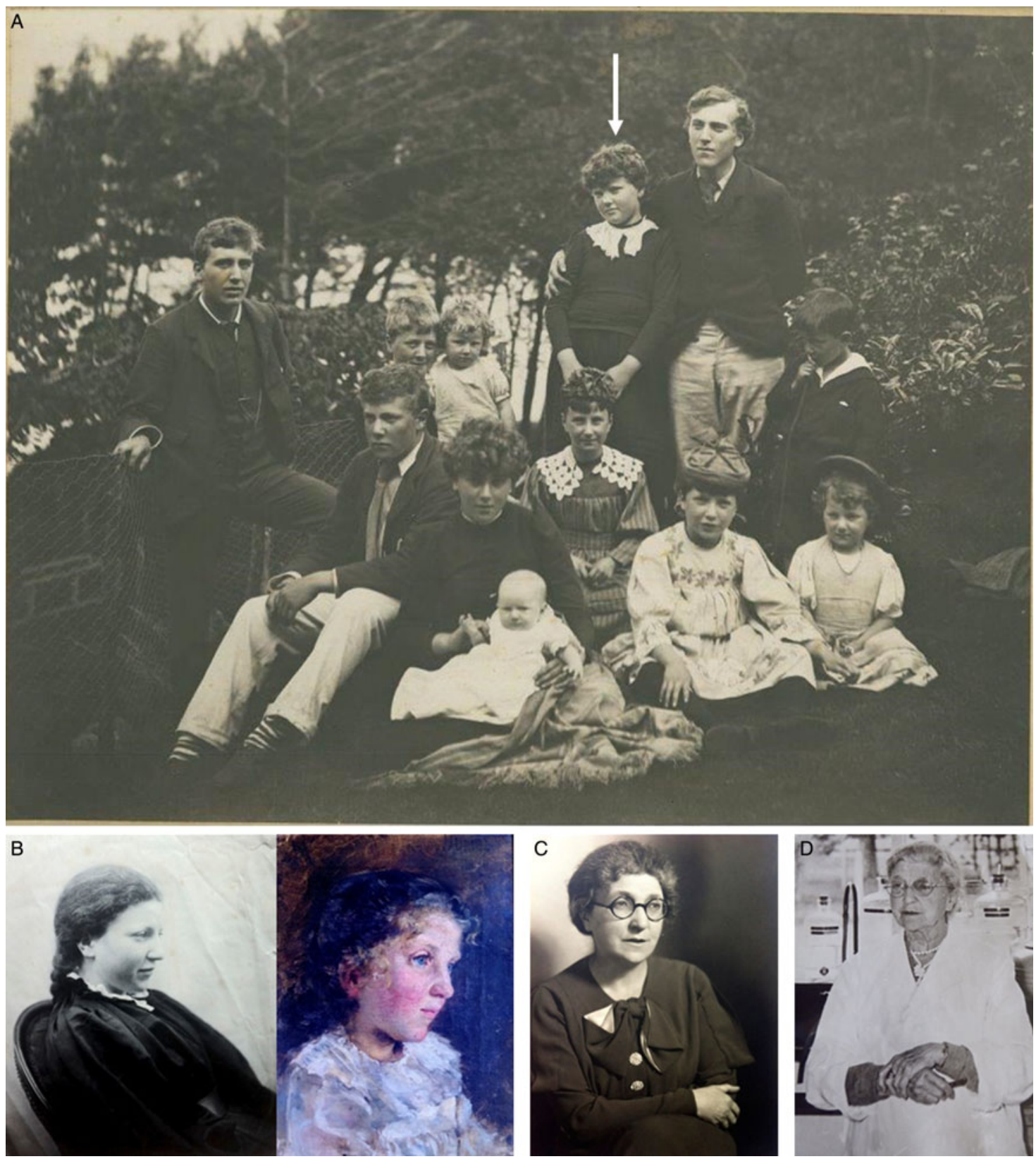

Fig. 1. (A) The Robertson siblings in 1892 or 1893. Clockwise from left: Edward Frederick (1872-1933), Jane Isabel (1880-?) holding Gertrude Llona ('Nonie'; 1889-1971), Muriel ('Moo Moo'; 1883-1973; indicated by arrow), Andrew Robert (1871-?), Frank Lesley (1887-?), Dorothy ('Do'; 1888-1975), Grace (1885-1971), Elizabeth ('Elsie') Mary (1878- 1950), Anna ('Nan’; 1881-?) holding Katherine Octavia (1892-1935), Maxwell ('Max’) Alexander (1874-1916). Dates of birth and death obtained from Ancestry.co.uk. (B) Muriel as a young girl (left) and as painted by her aunt, a member of the Royal Academy (right). (C) Muriel mid-career. (D) Muriel late-career. Photographs kindly provided by Penny Croutear (A and D) and from Dorothy Heard https://dorothyheard.wordpress.com/ (B and C).

Robertson, was a Londoner and an engineer, and although Muriel did not receive any formal scientific teaching until she went to university, her father helped to ensure that she absorbed science by osmosis. He would leave electrical apparatus out around the house for his children to play with, and discussed Darwin's theory with them. While working for the Mirrlees Watson Company in Glasgow, he was instrumental in persuading the managers/partners to initiate negotiations with Rudolf Diesel to gain a license to sell the Diesel engine in the $\mathrm{UK}$, which resulted in the introduction of the first Diesel engine into the UK in 1897, and in Diesel coming to stay in Muriel's house when she was 10. Additionally, Sir Robert Ball, FRS (founder of the Screw Theory), who was the Royal Astronomer of Ireland and had given several Royal Institution Christmas Lecturers at the turn of the twentieth century, was also a family friend, and stimulated an interest in astronomy and moral philosophy in Muriel. Muriel also learned to ride horses, and was encouraged to go on quite extensive 
expeditions in the Scottish Highlands during family holidays, which stimulated her love of travel. In later years, Muriel made great efforts to impart this love of travel to her nieces and nephews, choosing one each year to accompany her as a lady or gentleman-in-waiting on her summer holiday (https://dor othyheard.wordpress.com/). Given Aunt Muriel's formidable nature, her incredible zest for life and her efforts to expand her young charges' horizons in science, history and the arts (which she did via lengthy monologues with many digressions and changes of topic), these trips, although certainly exciting and memorable, may have also been rather exhausting.

Muriel's maternal grandmother, Jane Alexander, was also hugely influential during Muriel's childhood as Muriel spent months at a time in her care at the family farm at Limavady, Northern Ireland (Bishop and Miles, 1974). When she was a schoolgirl, Jane fell in love with her German music teacher, Edward Ritter, a liaison deeply opposed by her father. Jane and Edward therefore eloped, and then travelled to Australia, where Muriel's mother was born. There they made their fortune digging for gold before settling in Limavady when Jane became partial heiress to her brother's intestate estate, Dog Leap farm, in 1886. Jane was reported to have huge vitality and a great mind, characteristics which were also present in abundance in her granddaughter.

\section{University education}

Muriel's arts education made her initially plan for a career in music, but after her father died suddenly in 1900 while travelling to Argentina, she considered studying medicine for financial reasons (Bishop and Miles, 1974). However, her mother insisted that she should do an Arts degree first, and so she matriculated at the University of Glasgow in 1901 (Fig. 2). At this time, an Arts degree combined a range of subjects, and Muriel studied English, Italian and Latin, mathematics, logic, psychology and moral philosophy as well as botany and zoology under Graham Kerr and Edward Bles, studying some subjects alongside her sisters, Jane and Grace (University of Glasgow Matriculation Records, 1897-1905). Graham Kerr was very progressive for his time, insisting on teaching women alongside men, rather than separately as was the custom of the day, and gave Muriel bench space in his laboratory when she was a final year undergraduate. It may have only been a draughty corner of his laboratory, sandwiched between cases of teaching material, but this, combined with his strong interest in microscopy and protozoology, was instrumental in setting Muriel off on her varied and extensive studies of protozoa. As an undergraduate, Muriel was awarded a Carnegie Research Scholarship and rediscovered $P$. volvocis, a protozoan parasite of the freshwater green alga, Volvox, originally described by Cienkowski, discerning its complex life cycle and publishing her work in 1905 (Robertson, 1905), the same year that she graduated with an MA.

\section{Trypanosome research}

After graduating, she spent some time on the Isle of Bute, installing her microscope in the back of a fishmonger's shop in Rothesay to study the life cycle of the skate trypanosome, Trypanosoma raiae, in the leech, Pontobdella muricata, on live specimens caught from Rothesay Bay and around Bute. At the time, it was thought that trypanosomes were directly transmitted between hosts, but Muriel's work showed that the leech acted as a vector. She documented in detail the complex life cycle of the parasite within the leech, as well as features of its cell biology, including flagellum biogenesis and mitosis (Fig. 3) (Robertson, 1907b; 1909a). Muriel also studied the tissue distribution and cytology of the microsporidian, Ichthyosporidium, in flounder and sea trout, describing the multinucleate nature of the parasite as well as the appearance of an envelope that surrounded it (Robertson, 1907a; 1909b). Following this, Muriel was awarded a Carnegie Research Fellowship (1907-1910), which allowed her to travel to Sri Lanka (then Ceylon) in the summer of 1907 to study trypanosomes of reptiles at the National Museum at Colombo with the help of the curator, Arthur Willey. She elucidated the life cycle and described the cell biology of Trypanosoma vittatae in the aquatic milk tortoise, Emyda vittata, and in Glossiphonia leeches, providing strong evidence for Glossiphonia being the vector of $T$. vittatae (Robertson, 1909c), and also published notes on reptilian haematozoa (Robertson, 1908; 1910). In 1908, she returned to Glasgow before taking up a post at the Lister Institute of Preventative Medicine, London in 1909 as assistant to Edward Minchin, and being appointed as a member of staff (still as Minchin's assistant) in 1910. Edward Minchin was Chair of Protozoology at that time and worked on Trypanosoma lewisi in rats, and also on sponges, resulting in Muriel publishing work on the division of collar cells in sponges (Robertson and Minchin, 1910; Robertson, 1911a). She also collaborated with the Director of the Lister Institute, Charles Martin, to describe Trypanosoma eberthi and other intestinal parasites of fowl (Robertson and Martin, 1909; Martin and Robertson, 1911).

Additionally while at the Lister Institute, Muriel had access to a fishpond at the Institute's Hertfordshire site, Queensbury Lodge at Elstree (Fig. 4), where the goldfish were inevitably infected with Trypanoplasma and trypanosome parasites, as well as another artificial pond whose goldfish were not. This enabled her to embark on a series of 


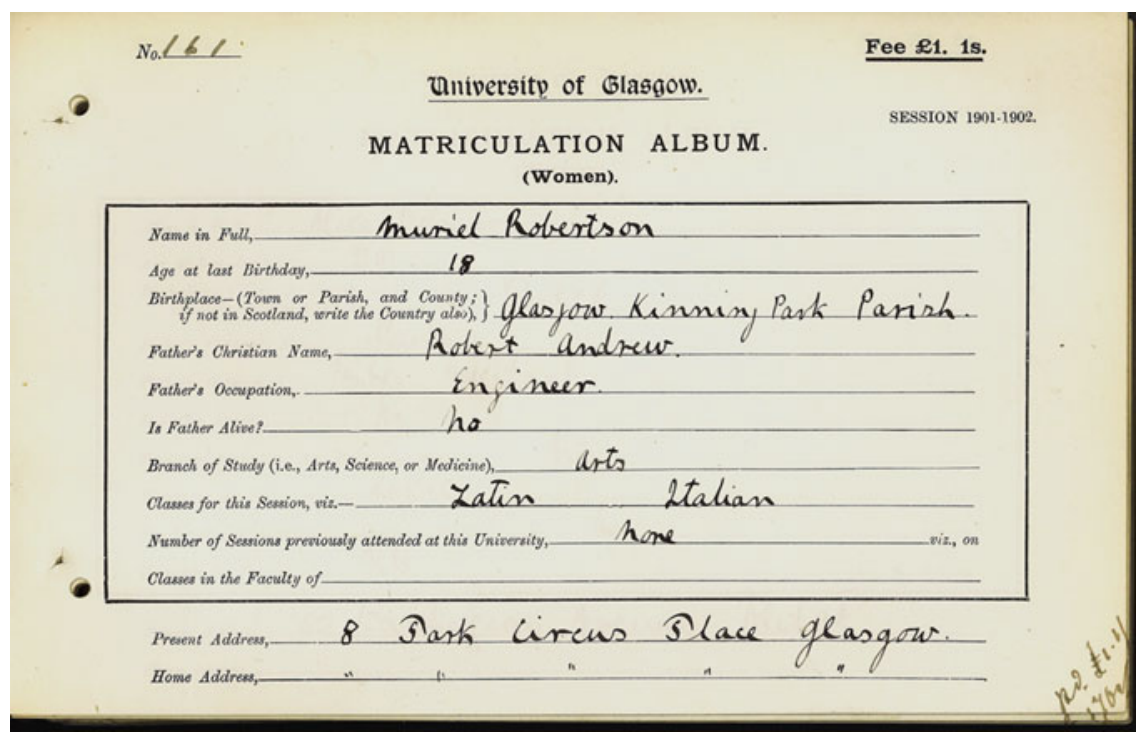

Fig. 2. Muriel's University of Glasgow matriculation record, 1901. University of Glasgow Archive Services, University Registry collection, GB248 R9/5/22/9.

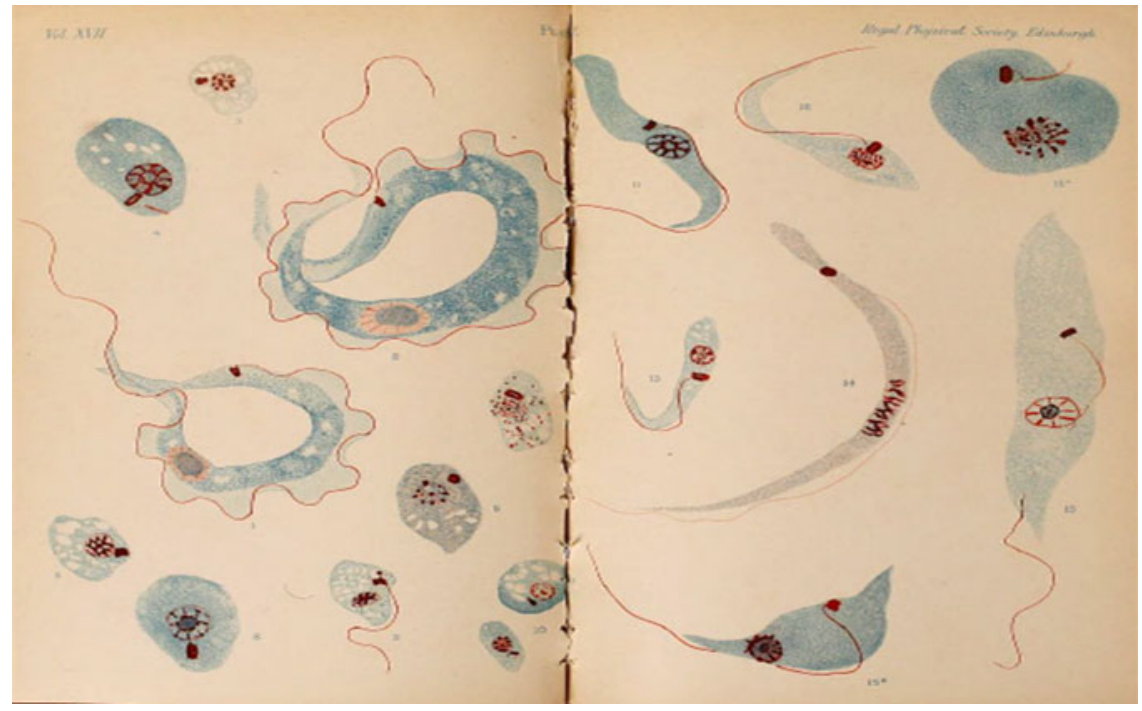

Fig. 3. Some of Muriel's sketches of T. raiae (Robertson, 1907b).

Trypanoplasma and trypanosome transmission experiments, using Hemiclepsis marginata leeches infected with the parasites, which she collected either from the Elstree pond or from the rushes surrounding a nearby reservoir. She was able to demonstrate that Trypanoplasma cyprini could be transmitted to goldfish via $H$. marginata, describing the passage of the Trypanoplasma from the crop of the leech to the proboscis-sheath (Robertson, $1911 b)$. She also showed that trypanosomes found in goldfish, perch, bream or rudd could complete their life cycle in clean $H$. marginata leeches (although $H$. marginata specimens from the wild were invariably infected with the parasites, their offspring at birth were not). She described the developmental cycle of the trypanosomes in the leech, and demonstrated that the leech could transmit trypanosomes between goldfish, and from perch or bream to goldfish (Robertson, 1911b). These were the first reported successful inter-species transmission experiments for fish trypanosomes. She also showed that adding water to trypanosomes in fish blood stimulated them to divide, which she suspected was due to the lowered osmotic pressure and, in her typical conscientious and rigorous fashion, she herself performed continuous live cell microscopy studies to document their division over a $23 \mathrm{~h}$ period, only occasionally being relieved by a colleague for a few minutes at a time (Robertson, 1911b).

Muriel's early research on trypanosomes and other parasites paved the way for her most significant research on trypanosomes. From 1900 to 1920 , a vast sleeping sickness epidemic occurred in Uganda, concentrated around the shores of Lake Victoria, which 


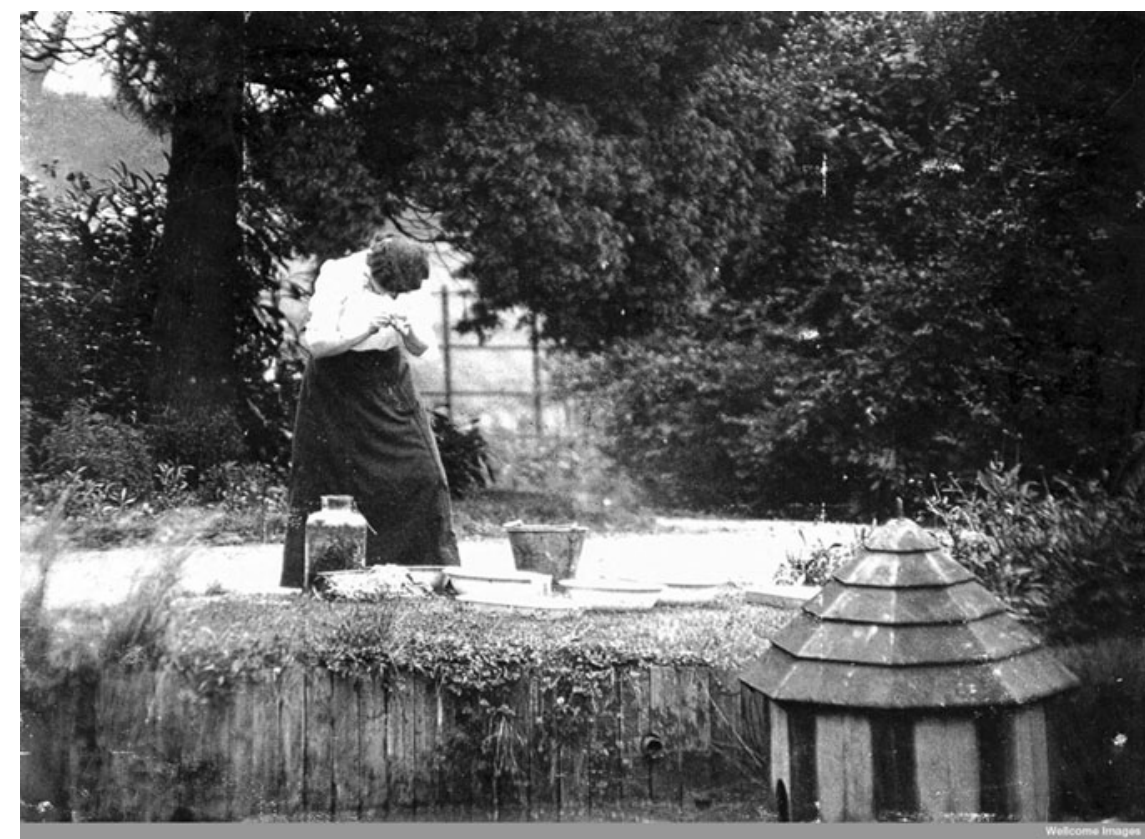

Fig. 4. Muriel fishing for leeches at the goldfish pond, Queensbury Lodge, Elstree 1910-11. L0019104; Credit: Wellcome Library, London; Muriel Robertson fishing for leeches; Photograph circa 1910; Collection: Archives and Manuscripts; Library reference no.: CMAC SA/LIS/RSI, CMAC and CMAC SA/LIS/RSI; Copyrighted work available under Creative Commons Attribution only licence CC BY 4·0 http://creativecommons.org/licenses/by/4.0/

saw a mass evacuation of people living within $24 \mathrm{~km}$ of the lake and resulted in $\sim 250000$ deaths, reducing the local population by one-third (Fevre et al. 2004; Berrang-Ford et al. 2006). The Royal Society had sent three Commissions to Uganda to study the disease in the early part of the 20th century, and Muriel was determined to go there herself to put her experience in studying the life cycles of trypanosomes in fish and reptiles to good use. With the blessing of Charles Martin, she accepted a temporary appointment from 1911-1913 as Protozoologist to the Protectorate of Uganda [with an annual salary of $£ 400$ /annum and free passage (The Royal Society Archives, 1911a)], joining Lyndhurst Duke at the Royal Society laboratories in Mpumu. This was no small undertaking, given that there was no effective treatment for sleeping sickness available at that time, and a member of the Royal Society's Second Commission had caught sleeping sickness and died as a result. However, Muriel did not apparently give much credence to such danger, remarking some years later in response to a questionnaire she was asked to complete about her time in Uganda 'There were tsetse fly in some of these places, but as regards that kind of danger it is ridiculous to talk of it seriously. Any nurse in a civil hospital in Europe runs more risk of infection with serious disease than one did in the actual investigation of sleeping sickness' (Fig. S1; University of Glasgow Archives, 1934). However, the fact that she, as a young woman, was appointed to such a post in Africa at that time was real testament to her scientific reputation, strength of character and courage.
Muriel's original research proposal for Uganda aimed to obtain a 'complete and detailed life-history of any well-developed pathogenic trypanosome' paying special attention to the fly stages and identifying the mammalian inoculative form of the parasite. She suggested that she would work on $T$. vivax and $T$. b. gambiense (then known as T. gambiense) as well as crocodile and toad trypanosomes ( $T$. grayi and $T$. $m e g a$, respectively) (The Royal Society Archives, $1911 b$ ). Muriel set off on her quest travelling by bicycle, accompanied by around 35 African porters and armed with a Mannlicher 30-30 rifle, which she used to shoot a crocodile blocking the way at a ford, later displaying the crocodile skin in her laboratory (Bishop and Miles, 1974) and then in her flat in Cambridge. Somewhat incongruously, she also took fine embroidery with her, which was her main pastime. It had been known since the turn of the 20th century from the work of David Bruce and Aldo Castellani (Bruce and Nabarro, 1903; Castellani, 1903b, c) that T. b. gambiense caused sleeping sickness, and that tsetse flies transmitted the parasite (Bruce et al. 1903; Castellani, 1903a), but transmission had initially been proposed to be direct. This misunderstanding had arisen from the design of one of Bruce's previous experiments; after feeding tsetse flies on an infected animal, he followed them up for just 6 days, noting that they lost infectivity $2448 \mathrm{~h}$ post-feed and did not regain it within this timeframe (Bruce, 1903). Friedrich Karl Kleine showed a few years later that $T . b$. brucei underwent a developmental cycle in the tsetse fly, Glossina palpalis (Kleine, 1909). Bruce and colleagues then confirmed 
this with T. b. gambiense (Bruce et al. 1909) and it was noted that tsetse flies became infective again 28 days post-infective feed once trypanosomes colonized the salivary glands (Bruce et al. 1911), yet the route trypanosomes took from the gut to the salivary glands remained a mystery. Further, long slender and short stumpy bloodstream form parasites were thought, by Fritz Schaudinn, Robert Koch, Kleine and others, based on analogy with malaria parasites, to be male and female parasites, respectively (Schaudinn, 1905).

Muriel's studies in Uganda led to the publication of five key papers describing various aspects of the T. b. gambiense life cycle (Robertson, 1912a, b, $c$; Robertson, $1913 a, b)$ and earned her a D.Sc. from the University of Glasgow in 1923 (Robertson, 1923). Working with Cercopithecus monkeys infected with T. b. gambiense, and regularly feeding uninfected tsetse flies on them, she described cyclical infective and latent periods to the tsetse fly that did not entirely correlate with the numbers of trypanosomes in a monkey's bloodstream (Robertson, $1912 a$ ). She went on to show that when parasite density was low, parasites were predominantly short and stumpy in appearance, and that these changed to parasites of intermediate and then long slender morphology (the dividing form) as parasite densities increased (Robertson, 1912c). This dismissed the male and female parasite theory by showing that the different forms were a morphological continuum. Previously, it had been suggested that latent parasites in organs such as the liver, spleen and lung might repopulate the blood and be responsible for the increase in parasitaemia, but Muriel's work showed that it was differentiation and division of parasites already in the blood that resulted in the rise in parasitaemia. She noted that immediately preceding the next drop in parasite density, short stumpy parasites once again made up the bulk of the population, and she proposed that harmful effects of serum were responsible for the subsequent drop in parasite density. She also noted that fluctuations in parasite density reflected ' $a$ continual state of tension......between the capacity of the host to destroy the parasite and the capacity of the parasite to maintain itself' (Robertson, 1912c), preempting later discovery of antigenic variation (Vickerman and Luckins, 1969; Vickerman, 1978). Her feeding experiments showed that tsetse fly infectivity correlated with the presence of the short stumpy parasites in the blood and she then showed that in the tsetse fly only the short stumpy forms established a dividing population in the gut, indicating that these were the tsetse infective form (Robertson, 1913b). However, this was to remain a controversial theory until Keith Vickerman demonstrated in 1965 that the stumpy form was metabolically adapted for life in the tsetse fly (Vickerman, 1965). Muriel also demonstrated that the parasites proceeded from the midgut of the fly to the proventriculus before eventually ending up in the salivary glands (Robertson, 1912b), thus solving the mystery of the trypanosome's passage through the tsetse fly that had eluded David Bruce and others. While other researchers of the time thought that salivary gland infection was unimportant, Muriel believed it to be the most crucial part of the whole life cycle. She suggested that salivary gland forms were responsible for transmitting the infection to mammals and also that the parasite sexual cycle might occur in the salivary glands (Robertson, 1913b), a theory that was only conclusively confirmed many years later by the Gibson and Carrington laboratories (Gibson et al., 2008; Peacock et al., 2011, 2014).

As well as studying T. b. gambiense in detail, Muriel also examined the life cycle of $T$. congolense (then known as T.nanum or T.pecorum) in the tsetse fly, demonstrating that although there were similarities between T. b.gambiense and T. congolense in their development in the tsetse fly gut, $T$. congolense was never present in the salivary glands, instead developing in the proboscis of the fly (Robertson, 1913b), observations that have been confirmed in a recent in-depth study of the $T$. congolense life cycle (Peacock et al. 2012). Whether Muriel also examined T. grayi or $T$. mega as she originally proposed is not clear, but in September 1912, she wrote to the Tropical Diseases Committee of the Royal Society stating that she would complete her studies on T. b. gambiense the following month and requesting permission to travel to the Wellcome laboratories in Khartoum for the last year of her posting to study Leishmania in dogs and to investigate fleas as a possible vector for the parasite (The Royal Society Archives, 1912a,c). This permission was denied, and instead she was requested to remain in Uganda (in the absence of Lyndhurst Duke who had left to go on an expedition) to carry out 'an investigation into an organism found in a hemipterous insect in Uganda' ('The Royal Society Archives, 1912b). However, it seems that this did not come to anything, and instead Muriel went on safari along the Masindi end of the main road that linked the Nile to the Congo and the Sudan (The Royal Society Archives, 1913e). This was an uninhabited area that she found to be 'simply full of game.... and seething with morsitans'. She investigated the prevalence of trypanosomes in the G. morsitans flies along the road and found that $10 \%$ flies were infected (with $T$. vivax, T. uniforme and T. congolense, but fortunately not human-infective trypanosomes), and that all cattle in the area were diseased (The Royal Society Archives, 1913e).

Muriel then undertook a longer trip through 120 miles of bush country in the Buruli district. By mapping G. morsitans distribution and talking to locals and officials during her travels, she was able to trace the introduction and spread of Nagana throughout the Masindi district of the Northern Province, the Kafu river district and Buruli region, 
demonstrating the importance of the game reservoir for the maintenance and spread of the disease (The Royal Society Archives, 1913d, $f, g)$. She concluded that a lack of precautions taken against Nagana when moving herds had led to over 3000 head of cattle being lost to the Protectorate and much of the country in the morsitans fly-belt being rendered permanently unfit for pasture due to the establishment of local game reservoirs. Muriel and others were deeply worried that if human-infective trypanosomes were to appear in this area, the unchecked passage of game through the $G$. morsitans belt in the Buruli district would spread them to the more populated Masindi port area, putting not only natives but many Europeans in the Protectorate at risk (The Royal Society Archives, 1913d). Indeed, given that Kleine and Fischer had recently showed that G. morsitans (previously considered the 'cattle' tsetse) was actually better adapted to transmit $T$. b. gambiense than G. palpalis (the 'sleeping sickness' tsetse) (Kleine and Fischer, 1913), the situation was grave. Although Muriel was due to go on leave in October 2013, her discovery in Kampala of a particularly virulent strain of trypanosome that had been isolated from antelope, led her to remain in Uganda until February 1914 in order to carry out tests to determine whether it was $T . b$. rhodesiense, which was limited to German East Africa at the time. Muriel later wrote 'there seems to be little doubt that we have got the trypanosome that goes by the name of $T$. rhodesiense already in the Uganda Protectorate' and urged that urgent measures be taken to prevent its further spread (The Royal Society Archives, 1913c).

The significance of Muriel's work was recognized by F. J. Jackson, the Governor to the Secretary of State of Uganda, in a letter to the Tropical Diseases Committee of the Royal Society in December 1913, in which he states: 'It is unnecessary to emphasize the grave danger to the health and prosperity of the Protectorate which Miss Robertson's discoveries have brought to light, and it remains only to consider the means by which this serious situation can be met' ('The Royal Society Archives, 1913b). The Governor recommended a range of investigative and preventative measures, based on Muriel's suggestions, including mapping tsetse fly distribution, limiting movement of cattle, quarantine of potentially infected animals and a ban on donkeys and mules being taken on safaris within the fly belts to halt the spread of trypanosomiasis. Rather controversially for the time, he also reiterated Muriel's recommendation that the amount of game living around the main road in the morsitans fly belt should be reduced, stating 'The protection of game in a morsitans area on a main road is an obviously suicidal measure' ('The Royal Society Archives, 1913b). He also ensured that the bush was cleared either side of the main road, as Muriel herself had recommended. C. A. Wiggins,
Acting Principal Medical Officer of the Uganda Protectorate, also wrote in strong support of these measures ('The Royal Society Archives, 1913a).

After Muriel's stay in Uganda came to an end, she was granted permission by the Tropical Diseases Committee in July 2014 to go to the Wellcome laboratories in Khartoum to investigate camel trypanosomes (The Royal Society Archives, 1914c). However, the political climate at the time due to the outbreak of World War I prevented her from going (The Royal Society Archives, 1914a, b) and she was diverted to work on bacteria.

\section{Work on anaerobic bacteria}

During World War I, Muriel studied anaerobic bacteria in war wounds. At the Lister Institute, she received gangrenous wound samples from Flanders and worked to develop culturing methods that would allow Clostridium spp. to be separated out as pure cultures. In her typical conscientious fashion and with great attention to detail, she examined samples from 42 war wounds alongside eight comparator Clostridial strains, using a dozen different growth media, some of which were quite complex to make, as well as performing biochemical assays and pathogenicity tests using guinea pigs (Robertson, 1916b). Modified formulations of the Cooked Meat Medium (containing minced bullock's heart) that she developed for these studies are today commercially available and widely used to cultivate anaerobic bacteria and to determine their proteolytic activity. Muriel also performed serological studies to allow different serotypes of pathogenic Clostridium to be distinguished (Robertson, 1920; Felix and Robertson, 1928; Robertson and Felix, 1930). Importantly, she showed that one antitoxin was able to protect against all four $C$. septicum serotypes she described. She also tried, unfortunately unsuccessfully, to develop a $C$. perfringens (then known as $C$. welchii) vaccine in guinea pigs (Robertson, $1916 a$ ). She surveyed wounds for the presence of tetanus bacilli and determined their toxigenic status (Robertson, 1917a), showing that the presence of toxigenic $C$. tetani did not inevitably lead to tetanus, and went to Elstree with Harriette Chick, a microbiologist who later made significant discoveries in the nutritional field with regards to preventing rickets (Copping, 1978), to assist in making tetanus antitoxin (Bishop and Miles, 1974). She also attended committee meetings in the War Office to discuss the problem of war wound infections, became secretary of the Anaerobes Committee of the Medical Research Council and contributed an extensive chapter on 'The organisms associated with gas gangrene' to the nine volume 'System of Bacteriology' published by the MRC (Robertson, 1929b).

Her World War I studies were not entirely devoted to anaerobic bacteria. She also spent some time trying 
to identify the causative agent of typhus. At that time, it was known that a patient's blood was infective if transferred to an experimental animal, and that the recipient animal became immune to reinfection, but there was much debate about the causative organism. Muriel received a coccus isolated from the blood of two typhus patients and the urine of a third, and attempted to infect monkeys with it (Robertson, 1917b). She used the killed coccus in immunization studies in monkeys, but the results of all of these experiments were negative - hardly a surprise today given that we now know that typhus fever is caused by rickettsial bacteria.

Muriel returned to studying anaerobic bacteria during World War II, studying C. perfringens at the Institute of Animal Pathology, Cambridge (to where she was evacuated with Hariette Chick) in collaboration with James Keppie (Bishop and Miles, 1974), a veterinarian and microbiologist who later, with Harry Smith, went on to discover the anthrax toxin (Smith and Keppie, 1954). Together, they tested the susceptibility of $C$. perfringens to newly available sulphonamide drugs and went on to compare $C$. perfringens toxin production in vitro with in vivo pathogenicity, demonstrating that high-level in vitro toxin producers were not always the most virulent strains in vivo (Robertson and Keppie, 1941; Keppie and Robertson, 1944). They also confirmed previous US studies that showed Clostridium toxoids conferred antitoxic immunity in experimental animals, showing that two doses of $C$. oedematiens and three doses of $C$. perfringens or $C$. septicum toxoids were required to completely protect mice after challenge (Robertson and Keppie, 1943). These data contributed to efforts in the UK to produce toxoid vaccines (which became available for general use towards the end of World War II) for soldiers and others at risk.

\section{Work on Bodo caudatus}

It was the mid-1920s before Muriel resumed work on protozoa after World War I. She initially set about using Robert Feulgen's recently developed DNA stain to study the cytology of the leech trypanosome $T$. raiae, the free-living flagellate $B$. caudatus, a relative of the parasitic trypanosomes (Robertson, 1927), and Heteromita globosa, a pear-shaped, freeliving biflagellate (Robertson, 1928). She demonstrated that the kinetoplasts of $T$. raiae and B. caudatus were Feulgen positive, as had already been shown for other Trypanosomatidae, including $T$. brucei by Bresslau and Scremin in 1924 (Bresslau and Scremin, 1924), and showed that there were differences in division of the nuclear DNA in these organisms. In $H$. globosa, she showed that its mitosis was similar to $T$. raiae, although failure of cytokinesis often led to binucleate cells reinitiating a new round of cell division, and she studied encystation and excystation (Robertson, 1928). She then went onto to perform some pioneering drug resistance studies on B. caudatus (Robertson, 1929a). Treatment with acriflavine resulted in a proportion (up to $75 \%$ ) of cells losing their kinetoplast, but never an entirely akinetoplastic population, and, in the absence of drug, cells with kinetoplasts would overgrow those without. Individual untreated clones showed differing sensitivities to the drug, which could be enhanced 4-fold by culturing B. caudatus continuously in the presence of drug; this resistance was gradually lost upon culture in the absence of the drug, but rapidly regained if acriflavine was again added to the culture, leading to Muriel to conclude that resistance was in part due to selection of the most resistant cells within the population and in part due to the drug modifying the organism. She also studied the effect of gamma irradiation on $B$. caudatus, showing that this treatment reduced its proliferation while increasing its size and affecting nitrogen metabolism (Robertson, 1932, 1935; Lawrie and Robertson, 1935).

Muriel's studies of anaerobic bacteria had stimulated her interest in immunology, and she wanted to combine this with her interest in the parasitic protozoa. However, other researchers had reported difficulties in maintaining parasitic protozoa under the conditions required for in vitro serum reactions, so Muriel chose to initially work on B. caudatus, which she adapted to isotonic Ringer's solution. By feeding it on a pure bacterial culture she was able, in animal immunization experiments, to easily distinguish between antibacterial and antiBodo antibodies, and to remove the antibacterial antibodies. She identified two types of specific antibody that would lyse B. caudatus in a complementdependent manner: a low-titre antibody from non-immunized animals and a high-titre antibody from immunized animals (Robertson, 1934). She also showed a similar phenomenon with ciliates from the Glaucoma-Colpidium group, and that the ciliates could secrete an enveloping sheath to protect themselves and to escape from the low-titre antibodies (Robertson, 1939b). Further, lytic antibodies were directed against a heat-labile antigen, while the sheath-inducing antibody recognized a heat-stable antigen (Robertson, 1939a).

\section{Immunology and Trichomonas}

After her initial foray into immunology with B. caudatus and ciliates, Muriel moved on, in 1938, to study the immunology of trichomoniasis infections in cattle with W. R. Kerr from the Ministry of Agriculture in Northern Ireland, a collaboration that was to last for some 20 years. Up until this point, T. foetus had been regarded as a commensal microbe of the genital tract in cattle and had not been linked to the infertility and spontaneous abortion that was associated with trichomoniasis. Kerr, 
a veterinarian, had come across a large outbreak of trichomoniasis, and had noticed that the uterine cavity of infected cows was filled with trichomonads. He was acquainted with Muriel's sister, Dorothy, a well-known figure in Northern Irish agriculture she was a dairy farmer at Dog Leap farm in Limavady and also an expert on pigs and a breeder of Kerry cattle and Light Sussex poultry. It was through Dorothy that Kerr knew of Muriel's longstanding interest in the protozoa, and he phoned her at the Lister Institute to tell her of his findings. Muriel was so excited by his news that she immediately flew to Belfast to meet with Kerr. From then on, they exchanged protocols weekly by post and they each spent a week annually in each other's laboratory (Bishop and Miles, 1974).

Muriel and Kerr devised a culture medium for Trichomonas and developed a diagnostic agglutination test for trichomoniasis (Kerr and Robertson, 1941; Robertson, 1941). They studied the antibody response to $T$. foetus in both infected and uninfected animals, revealing the presence of a high-titre response ('immune agglutinins') in the sera of some, but not all infected cattle, which was capable of inducing passive anaphylactic hypersensitivity, and a low-titre response ('normal agglutinins') in the sera of uninfected as well as some infected animals, which was not (Kerr and Robertson, 1943). Both antibody types were lytic in the presence of complement, and Muriel and Kerr showed that they were transmitted to newborn calves via colostrum immediately post-partum, but then disappeared from the blood within a few weeks, at which point, the calves would start to make their own normal agglutinins, apparently in the absence of any antigenic stimulus (Kerr and Robertson, 1946b).

Muriel and Kerr then went on to determine the conditions required to artificially infect heifers with the parasite and mimic the natural symptoms of the disease (Kerr and Robertson, 1946a). Vaginal instillation proved unsuccessful; although infection occurred, there were no effects on fertility, and it turned out that intrauterine instillation of $T$. foetus during oestrus (i.e. soon after mating or in the presence of semen) was required to affect fertility. In unmated animals, the intrauterine inoculum would be cleared within 3 weeks, demonstrating a self-sterilizing activity of the uterus that was ultimately exploited to eradicate the disease from N. Ireland. In bulls, $T$. foetus lives as a commensal organism in the preputial penile sheath, and thus constitutes a reservoir of infection. In the absence of a way to get rid of the parasites, infected bulls were destroyed, and all potentially infected females were left unmated for 6 weeks to allow them to clear any trichomonads from their genital tract. This had a dramatic effect and resulted in the eradication of infertility and abortion due to trichomoniasis in $\mathrm{N}$. Ireland within 2-3 years (Miles, 1976).

Muriel and Kerr also went on to investigate the nature of the immune response to $T$. foetus, demonstrating the importance of a local antibody response in Trichomonas immunity. It is useful to emphasize first that Trichomonas infection is self-limiting while it causes abortion and in some cases infertility, parasites can be spontaneously cleared from infected animals and a certain amount of immunity to future exposure occurs. It had been puzzling that circulating serum antibodies were not always generated in response to infection, or indeed to injection of $T$. foetus extracts into the uterus. However, despite the absence of circulating antibody, infection or administration of extracts could sensitize animals to further intrauterine inoculation. Conversely, while intramuscular vaccination of virgin heifers with live parasites resulted in the generation of high-titre antibodies and anaphylactic sensitization of the skin, it did not protect against intrauterine infection. Interestingly, this skin sensitivity temporarily decreased immediately after parturition, most likely due to vastly increased corticosteroid concentrations in the blood (Kerr et al., 1949, 1951). Muriel and Kerr went on to show that specific protective antibodies were present in uterine and vaginal secretions following $T$. foetus infection or local administration of antigen, despite few or none of these antibodies entering the circulation (Kerr and Robertson, 1953). Furthermore, a local anaphylactic-type sensitivity reaction could be stimulated by repeated intrauterine instillation of antigen (Kerr and Robertson, 1953).

Muriel and Kerr also contributed to general immunology with their description of immunological paralysis in the newborn calf (Kerr and Robertson, 1956). They observed that young calves $(<4$ weeks old) did not generate any antibodies to $T$. foetus antigens administered intramuscularly. Where they had been exposed to a low dose of antigen shortly after birth, they would subsequently, when re-challenged, produce antibodies. However, if they were exposed to high doses of antigen when young, their immune response to subsequent antigen challenge was impaired over a substantial period (Kerr and Robertson, 1956). Muriel's final contribution to the Trichomonas scientific literature was a chapter in the book Immunity to Protozoa following a symposium of the British Society of Immunology in 1961 (Robertson, 1963a).

\section{Awards and learned society membership}

Muriel's ground-breaking research in protozoology and bacteriology was officially recognized in 1947 when she became the eighth woman to have been elected a Fellow of the Royal Society (FRS), just two years after Marjory Stephenson and Kathleen 
Lonsdale became the first women recipients of the award. To put the significance of this award into context, future Nobel prize-winning biochemists Dorothy Hodgkin and Hans Krebs, as well as the Prime Minister of the day, Clement Atlee, were amongst those elected FRS in 1947. Proposers of Muriel for this award included Graham Kerr, Charles Martin, Alexander Fleming, and malariologist and medical entomologist, Sydney Price James (The Royal Society Archives, 1944). Muriel was awarded an Honorary Doctorate in Law (LLD) at the University of Glasgow the following year, an honour which evidently delighted her, given her comments in her acceptance letter: 'The invitation of the Senate has naturally caused me the very greatest pleasure if also some surprise. The happy obscurity in which I have always worked makes an honour such as this most unexpected. I am very happy indeed to accept the Hon. L.L.D. degree and should like to express my thanks to the Senate. Any recognition from one's own University has always a particularly pleasing quality' (University of Glasgow Archives, 1948). During her career, Muriel was also made a fellow of the Royal Society of Tropical Medicine and the Institute of Biology, and was a member of the Medical Research Club, the Society for Experimental Biology and the Pathological Society. She was a founding member of the Society for General Microbiology (SGM), serving on its council from 1945-1948 and was made an Honorary Member in 1962. She was invited by the SGM to give the Marjory Stephenson Memorial Lecture in 1963 on the occasion of her eightieth birthday (Robertson, 1963b). She was also made an Honorary Member of the British Society for Parasitology. Posthumously, Muriel was a nominee for the Saltire Society Scotland 'Outstanding Women of Scotland' award in 2014.

\section{Retirement}

Muriel worked at the Lister Institute until 1961, more than a decade after her official retirement at age 65 . In the late $1950 \mathrm{~s}$, due to acute glaucoma, she had to have one eye removed. Despite this tragic event, she was able to adapt to her reduced vision, and continued work for several more years. However, life in London was now too taxing and she moved back to Cambridge, where some of her relatives then lived, working part time at the Agricultural Research Council Institute of Animal Physiology at Babraham, in the laboratory of one of her former PhD students, Alan Pierce. She continued her antigenic analysis of $T$. foetus strains using double-diffusion precipitation in an agar gel (Robertson, 1960), but after 18 months, with worsening health, decided she could no longer reach the high standards she set herself. She retired and moved back to Limavady to live with her sister
Dorothy at Dog Leap Farm. However, she still made annual trips to England to visit family, friends and former colleagues, and even, on occasion, to attend a scientific meeting, until this became too much for her. Her last 18 months were spent in hospital in Limavady, and she died, aged 90, on 14th June 1973.

\section{Concluding remarks}

Muriel Robertson was, undeniably, a remarkable scientist, having achieved a long and distinguished career in the fields of parasitology, bacteriology and immunology. The number of organisms she worked (and published) on, the depth of her observations and the volume of work she completed was, even compared with today's standards, quite extraordinary. It is remarkable that she was able to record such detailed cytological observations of her organisms of study in the absence of the highpower fluorescent and electron microscope imaging, or even electronic image capture systems that most of us take for granted today, that she devised ways of cultivating so many organisms in her laboratory in the absence of published protocols or commercial availability of ready-made reagents or media, and that she was able to make such discerning predictions about the biology of these organisms in the absence of molecular biology, and (until the last decade of her career), even any knowledge of DNA structure. Add to this that she started out her career in Edwardian times when women were usually taught separately from men and much of the education they received was to prepare them for marriage and running a household, when only a quarter of women worked, with a number of careers being closed to them, and when women did not have the right to vote, her achievements are simply staggering. In scientific circles, she could be, perhaps not surprisingly, a formidable force, who did not suffer fools gladly (reports of her 'piercing intellect and devastating tongue' abound). She was extremely rigorous and was not afraid of challenging anyone, whatever their status, whose methods or conclusions she disagreed with. Equally, she was very conscientious about acknowledging the help she received from her colleagues and collaborators. She also expended considerable effort in trying to broaden the horizons of the younger generation beyond science, would willingly try to assist anyone who asked for her help and did much to nurture her protégées in her laboratory, often keeping in touch with them for many years. However, despite her illustrious career and many successes in challenging environments, there was just one situation in which she could not feel comfortable, as Keith Vickerman (Vickerman and Sleigh, 2000) overheard her admit at a reception at the 1961 British Society of Parasitology meeting 
organized to celebrate the resolution taken to found the British Section of the Society of Protozoologists:

'Hell cannot possibly have any torment to compare with the modern cocktail party'.

\section{SUPPLEMENTARY MATERIAL}

The supplementary material for this article can be found at https://doi.org/10.1017/S0031182016002080.

\section{ACKNOWLEDGEMENTS}

I would like to thank Muriel Robertson's great nieces, Penny Croutear and Priscilla Heard, for very interesting and informative discussions about Muriel and to Penny for providing Robertson family photographs. I would also like to acknowledge Muriel's niece, Dorothy Heard, whose online blog about the Robertson family provided many useful details and photographs of Muriel. I would also like to thank Rachael Egan of the University of Glasgow Archive Service for providing copies of Muriel Robertson's correspondence and Vickie Curtis, Public Engagement Manager of the Wellcome Trust Centre for Molecular Parasitology for her help and support with this project.

\section{FINANCIAL SUPPORT}

This research was funded by the Institute of Infection, Immunity and Inflammation, University of Glasgow.

\section{REFERENCES}

Berrang-Ford, L., Odiit, M., Maiso, F., Waltner-Toews, D. and McDermott, J. (2006). Sleeping sickness in Uganda: revisiting current and historical distributions. African Health Sciences 6, 223-231.

Bishop, A. and Miles, A. (1974). Muriel Robertson, 1883-1973. Biographical Memoirs of Fellows of the Royal Society 20, 317-347.

Bresslau, E. Z. and Scremin, L. (1924). Die Kerne der Trypanosomen und ihr Verhalten zur Nuclealreaktion. Archiv Protistenkunde 48, 509-515. Bruce, D. (1903). Appendix to Further Report on the Tsetse Fly Disease or Nagana in Zululand. Harrison and Sons, London.

Bruce, D. and Nabarro, D. (1903). Progress report on sleeping sickness in Uganda. Reports of the Sleeping Sickness Commission 1, 11-88.

Bruce, D., Nabarro, D. and Greig, E. D. W. (1903). Further report on sleeping sickness in Uganda. Reports of the Sleeping Sickness Commission 4, 1-87.

Bruce, D., Hamerton, A. E., Bateman, H. R. and Mackie, F. P. (1909). The development of Trypanosoma gambiense in Glossina palpalis. Proceedings of the Royal Society of London Series B: Biological Sciences 81, 405-414.

Bruce, D., Hamerton, A. E., Bateman, H. R. and Mackie, F. P. (1911). Further researches on the development of Trypanosoma gambiense in Glossina palpalis. Proceedings of the Royal Society of London B: Biological Sciences 83, 513-527.

Castellani, A. (1903a). Adult forms and developmental forms of the trypanosome found in sleeping sickness. Reports of the Sleeping Sickness Commission 2, 9-13.

Castellani, A. (1903b). On the discovery of a species of Trypanosoma in the cerebro-spinal fluid of cases of sleeping sickness. Proceedings of the Royal Society of London B: Biological Sciences 71, 501-508.

Castellani, A. (1903c). Presence of Trypanosoma in sleeping sickness. Reports of the Sleeping Sickness Commission 1, 3-10.

Copping, A. M. (1978). Obituary notice - Dame Harriette Chick. British Fournal of Nutrition 39, 3-5.

Felix, A. and Robertson, M. (1928). Serological studies in the group of spore-bearing anaerobes. I. Qualitative analysis of the bacterial antigens of B. oedematis maligni (Vibrion septique) and B. tetani. British Yournal of Experimental Pathology 9, 6-18.

Fevre, E. M., Coleman, P. G., Welburn, S. C. and Maudlin, I. (2004). Reanalyzing the 1900-1920 sleeping sickness epidemic in Uganda. Emerging Infectious Diseases 10, 567-573.
Gibson, W., Peacock, L., Ferris, V., Williams, K. and Bailey, M. (2008). The use of yellow fluorescent hybrids to indicate mating in Trypanosoma brucei. Parasites and Vectors 1, 4.

Keppie, J. and Robertson, M. (1944). The in-vitro toxigenicity and other characters of strains of $\mathrm{Cl}$. welchii type A from various sources. Fournal of Pathology and Bacteriology 56, 123-132.

Kerr, W. R. and Robertson, M. (1941). An investigation into the infection of cows with $T$. foetus by means of the agglutination reaction. Veterinary fournal 97, 351-363.

Kerr, W. R. and Robertson, M. (1943). A study of the antibody response of cattle to Trichomonas foetus. Fournal of Comparative Pathology and Therapeutics 53, 280-297.

Kerr, W. R. and Robertson, M. (1946a). Experimental infections in virgin heifers with Trichomonas foetus in vaccinated and unvaccinated animals. Fournal of Comparative Pathology and Therapeutics 6, 101-113.

Kerr, W. R. and Robertson, M. (1946b). A study of the passively acquired antibody to $T r$. foetus in the blood of young calves and its behaviour in agglutination tests and intradermal reactions. Fournal of Comparative Pathology and Therapeutics 56, 38-48.

Kerr, W. R. and Robertson, M. (1953). Active and passive sensitization of the uterus of the cow in vivo against Trichomonas foetus antigen and the evidence for the local production of antibody in that site. Fournal of Hygiene (London) 51, 405-415.

Kerr, W. R. and Robertson, M. (1956). Partial immunological paralysis to Trichomonas foetus antigen in calves. Fournal of Hygiene (London) 54, 415-418. Kerr, W. R., McGirr, J. L. and Robertson, M. (1949). Specific and nonspecific desensitisation of the skin in Trichomonas sensitive bovines. Fournal of Comparative Pathology and Therapeutics 59, 133-154.

Kerr, W. R., Robertson, M. and McGirr, J. L. (1951). A study of the reaction of the white blood corpuscles in bovines at parturition with a consideration of the evidence of the action of the adrenal cortical hormone (cortisone). Fournal of Hygiene (London) 49, 67-80.

Kleine, F. K. (1909). Weitere wissenschaftliche Beobachtungen über die Entwicklung von Trypanosomen in Glossinen. Deutsche Medizinische Wochenschrift 35, 924-925.

Kleine, F. K. and Fischer, W. (1913). Schlafkrankheit und Tsetsefliegen. Zeitschrift fuer Hygiene und Infektionskrankheiten 75, 375-382.

Lawrie, N. R. and Robertson, M. (1935). The effect of gamma-ray irradiation upon the growth and nitrogenous metabolism of the protozoon, Bodo caudatus. Biochemical Fournal 29, 1017-1020.

Martin, C. H. and Robertson, M. (1911). Further observations on the caecal parasites of fowls, with some reference to the rectal fauna of other vertebrates quarterly. Fournal of Microscopical Science 57, 53-81.

Miles, A. A. (1976). Obituary: Muriel Robertson, 1883-1973. Fournal of General Microbiology 95, 1-8.

Peacock, L., Ferris, V., Sharma, R., Sunter, J., Bailey, M. Carrington, M. and Gibson, W. (2011). Identification of the meiotic life cycle stage of Trypanosoma brucei in the tsetse fly. Proceedings of the National Academy of Sciences of the United States of America 108, 3671-3676. Peacock, L., Cook, S., Ferris, V., Bailey, M. and Gibson, W. (2012). The life cycle of Trypanosoma (Nannomonas) congolense in the tsetse fly. Parasites and Vectors 5, 109.

Peacock, L., Bailey, M., Carrington, M. and Gibson, W. (2014). Meiosis and haploid gametes in the pathogen Trypanosoma brucei. Current Biology 24, 181-186.

Robertson, M. (1905). Pseudospora volvocis Cienkowski. Quarterly fournal of Microscopical Science 49, 213-230.

Robertson, M. (1907a). Notes upon a haplosporidian belonging to the genus Ichthyosporidium. Proceedings of the Royal Physical Society of Edinburgh 17, 175-187.

Robertson, M. (1907b). Studies on a trypanosome found in the alimentary canal of Pontobdella muricata. Proceedings of the Royal Physical Society of Edinburgh 17, 83-108.

Robertson, M. (1908). A preliminary note on haematozoa from some Ceylon reptiles. Spolia Zeylanica 5, 178-185.

Robertson, M. (1909a). Further notes on a trypanosome found in the alimentary tract of Pontobdella muricata. Quarterly Fournal of Microscopical Science 54, 119-131.

Robertson, M. (1909b). Notes on an ichthysporidian causing a fatal disease in sea trout. Proceedings of the Zoological Society of London 2, 399-402.

Robertson, M. $(1909 c)$. Studies on Ceylon haematozoa. No. 1. The life cycle of Trypanosoma vittatae. Quarterly Fournal of Microscopical Science 53, 655-695.

Robertson, M. (1910). Studies on Ceylon haematozoa. No. II. Notes on the life-cycle of Haemogregarina nicoriae Cast. and Willey. Quarterly Fournal of Microscopical Science 55, 741-762.

Robertson, M. (1911a). The division of the collar-cells of the Calcarea heterocoela. Quarterly Yournal of Microscopical Science 57, 129-139. 
Robertson, M. (1911b). Transmission of flagellates living in the blood of certain freshwater fishes. Philosophical Transactions of the Royal Society of London B: Biological Sciences 202, 29-50.

Robertson, M. (1912a). Notes on certain aspects of the development of Trypanosoma gambiense in Glossina palpalis. Proceedings of the Royal Society of London B: Biological Sciences 85, 241-248.

Robertson, M. (1912b). Notes on the life-history of Trypanosoma gambiense etc. Proceedings of the Royal Society of London B: Biological Sciences 86, 66-71.

Robertson, M. (1912c). Notes on the polymorphism of Trypanosoma gambiense in the blood and its relation to the exogenous cycle in Glossina palpalis. Proceedings of the Royal Society of London B: Biological Sciences 85, 527-539. Robertson, M. (1913a). Notes on the behaviour of a polymorphic trypanosome in the blood-stream of the mammalian host. Reports of the Sleeping Sickness Commission Royal Society 13, 111-119.

Robertson, M. (1913b). Notes on the life-history of Trypanosoma gambiense, with a brief reference to the cycles of Trypanosoma nanum and Trypanosoma pecorum in Glossina palpalis. Philosophical Transactions of the Royal Society of London B: Biological Sciences 203, 161-184.

Robertson, M. (1916a). Notes on the vaccination of guinea-pigs with $B$. perfringens. Lancet ii, 516-518.

Robertson, M. (1916b). Notes upon certain anaerobes isolated from wounds. Fournal of Pathology and Bacteriology 20, 327-349.

Robertson, M. (1917a). Notes on the occurrence of B. tetani in wounds. Transactions of the Royal Society of Tropical Medicine and Hygiene 11, $56-58$

Robertson, M. (1917b). Typhus fever. An experiment on vaccination with a coccus derived from human cases. Fournal of Pathology and Bacteriology 21, 173-183.

Robertson, M. (1920). Serological groupings of Vibrion septique and their relation to the production of toxin (with a note on chymographic experiments by H. H. Dale). Fournal of Pathology and Bacteriology 23, 153-170. Robertson, M. (1923). A study of the life-histories of certain trypanosomes. D.Sc. thesis, University of Glasgow, Glasgow.

Robertson, M. (1927). Notes on certain points in the cytology of Trypanosoma raiae and Bodo caudatus. Parasitology 19, 375-393.

Robertson, M. (1928). Notes on Heteromita (Protozoa, Flagellata). Parasitology 20, 10-24.

Robertson, M. (1929a). The action of acriflavine upon Bodo caudatus. Parasitology 21, 375-416.

Robertson, M. (1929b). The organisms associated with gas gangrene. In $A$ System of Bacteriology, Vol. 3. pp. 225-297. His Majesty's Stationery Office, London.

Robertson, M. (1932). The effect of gamma-ray radiation upon the growth of a protozoon, Bodo caudatus. Quarterly Fournal of Microscopical Science 75, 511-541.

Robertson, M. (1934). An in vitro study of the action of immune bodies called forth in the blood of rabbits by the injection of the flagellate protozoon Bodo caudatus. Fournal of Pathology and Bacteriology 38, 363-390. Robertson, M. (1935). On the reduction in the multiplication of a protozoon (Bodo caudatus) caused by the exposure to gamma-ray irradiation with a study of the sensitive period in the life of the cell. British fournal of Radiology 8, 502-526.

Robertson, M. (1939a). An analysis of some of the antigenic properties of certain ciliates belonging to the Glaucoma-Colpidium group as shown in their response to immune serum. Fournal of Pathology and Bacteriology 48, 323-338. Robertson, M. (1939b). A study of the reactions in vitro of certain ciliates belonging to the Glaucoma-Colpidium group to antibodies in the sera of rabbits immunized therewith. Fournal of Pathology and Bacteriology 48, 305-322.

Robertson, M. (1941). Agglutination reactions of certain trichomonads in sera obtained from immunized rabbits, with particular reference to Trichomonas foetus. Fournal of Pathology and Bacteriology 53, 391-402.

Robertson, M. (1960). The antigens of Trichomonas foetus isolated from cows and pigs. Fournal of Hygiene (London) 58, 207-213.

Robertson, M. (1963a). Antibody response in cattle to infection with Trichomonas foteus. In Immunity to Protozoa. A symposium of the British Society of Immunology (eds. Garnham, P. C.C., Pierce, E. A. and Roitt, I.), pp. 336-345. Blackwell Scientific Publications, Oxford.

Robertson, M. (1963b). Some aspects of the protozoa and their way of life. Fournal of General Microbiology 33, 177-189.

Robertson, M. and Felix, A. (1930). Serological studies in the group of the spore-bearing anaërobes. II. In vivo experiments with an "O" immune serum to Vibrion septique devoid of antitoxin content. British Fournal of Experimental Pathology 11, 14-23.

Robertson, M. and Keppie, J. (1941). In-vitro production of toxin from strains of $\mathrm{Cl}$. welchii recently isolated from war wounds and air raid casualties. Fournal of Pathology and Bacteriology 53, 95-104.
Robertson, M. and Keppie, J. (1943). Gas gangrene. Active immunization by means of concentrated toxoids. Lancet ii, 311-318.

Robertson, M. and Martin, C.H. (1909). Preliminary note on Trypanosoma eberthi (Kent) (Spirochaeta eberthi, Luehe) and some other parasitic forms from the intestine of the fowl. Proceedings of the Royal Society of London Series B: Biological Sciences 81, 385-391.

Robertson, M. and Minchin, E. A. (1910). The division of the collar-cells of Clathrina coriacea (Montagu): a contribution to the theory of the centrosome and blepharoplast. Quarterly Fournal of Microscopical Science 55, 611-640. Schaudinn, F. (1905). Dr Schaudinn's work on blood parasites. British Medical fournal 1, 442-444.

Smith, H. and Keppie, J. (1954). Observations on experimental anthrax: demonstration of a specific lethal factor produced in vivo by Bacillus anthracis. Nature 173, 860-870.

The Royal Society Archives (1911a). Minutes of the Tropical Diseases Committee. GB 117 The Royal Society, CMB/51/15.

The Royal Society Archives (1911b). Programme of proposed research, submitted by Muriel Robertson to the Royal Society Tropical Diseases Committee. GB 117 The Royal Society, CMB/51/15.

The Royal Society Archives (1912a). Letter from Miss Muriel Robertson, Mpumu, Uganda to the Secretaries of the Royal Society. $G B$ 117 The Royal Society, CMB/51/42.

The Royal Society Archives (1912b). Minutes of the Tropical Diseases Committee. GB 117 The Royal Society, CMB/51/44

The Royal Society Archives (1912c). Programme of proposed work, 1912-1913, prepared for the Tropical Diseases Committee by Miss Muriel Robertson. GB 117 The Royal Society, CMB/51/43.

The Royal Society Archives (1913a). Letter from C. A. Wiggins, Acting Principal Medical Officer, Uganda Protectorate, Entebbe, to the Chief Secretary of the Uganda Protectorate GB 117 The Royal Society, CMB/ $51 / 76$

The Royal Society Archives (1913b). Letter from F. J. Jackson, Governor of Uganda, to the Secretary of State. GB 117 The Royal Society, CMB/51/73

The Royal Society Archives (1913c). Letter from Muriel Robertson, Kampala, Uganda, to the Secretary of the Royal Society. GB 117 The Royal Society, CMB/51/70.

The Royal Society Archives (1913d). Letter from Muriel Robertson, Kampala, Uganda, to the Secretary of the Royal Society. GB 117 The Royal Society, CMB/51/69.

The Royal Society Archives (1913e). Letter from Muriel Robertson, the camp, Northern Province Uganda, to the Secretary of the Royal Society. GB 117 The Royal Society, CMB/51/68.

The Royal Society Archives (1913f). Report on the present condition of the Kafu River District and of Buruli in regard to the spread of Trypanosomiasis. GB 117 The Royal Society, CMB/51/75.

The Royal Society Archives (1913g). Report on the present condition of the Masindi District of the Northern Province in regard to cattle Trypanosomiasis. GB 117 The Royal Society, CMB/51/74.

The Royal Society Archives (1914a). Letter from H. J. Read, for the Under Secretary, Colonial Office Downing Street, to the Secretaries of the Royal Society GB 117 The Royal Society, CMB/51/88.

The Royal Society Archives (1914b). Letter from H. J. Read, for the Under Secretary, Colonial Office Downing Street, to the Secretaries of the Royal Society GB 117 The Royal Society, CMB/51/87.

The Royal Society Archives (1914c). Minutes of the Tropical Diseases Committee. GB 117 The Royal Society, CMB/51/85.

The Royal Society Archives (1944). Certificate of a Candidate for Election: Muriel Robertson. GB 117 The Royal Society, EC/1947/22.

University of Glasgow Archives (1934). Correspondence between Miss Melville and Muriel Robertson. University of Glasgow Archive Services, Queen Margaret College Collection, GB248 DC 233/2/10/7/11

University of Glasgow Archives (1948). Correspondence concerning Muriel Robertson's Honorary degree from the University of Glasgow, June 1948. Papers of Honorary Graduations, University of Glasgow Archives and Special Collections, Acc 44/3.

University of Glasgow Matriculation Records (1897-1905). Records of the University Registrar Department. University of Glasgow Archives and Special Collections, R8/5.

Vickerman, K. (1965). Polymorphism and mitochondrial activity in sleeping sickness trypanosomes. Nature 208, 762-766.

Vickerman, K. (1978). Antigenic variation in trypanosomes. Nature 273, 613-617.

Vickerman, K. and Luckins, A. G. (1969). Localization of variable antigens in the surface coat of Trypanosoma brucei using ferritin conjugated antibody. Nature 224, 1125-1126.

Vickerman, K. and Sleigh, M. A. (2000). A Century of Protozoology in Britain. British Section of the Society of Protozoologists. 